\title{
GENETIC TYPE AND GROWTH INFLUENCE ON THE PRODUCTION CHARACTERISTICS OF LIGHT LINE HEN HYBRIDS**
}

\author{
V. Rajicic ${ }^{1}$, S. Mitrovic ${ }^{2}$, S. Bogosavljevic-Boskovic ${ }^{3}$, \\ J. Milivojevic ${ }^{1}$, M. Staletic ${ }^{1}$, V. Djermanovic ${ }^{2}$, N. Tolimir ${ }^{4}$ \\ ${ }^{1}$ Small Grains Research Center, Kragujevac, $34000 ;{ }^{2}$ Faculty of Agryculture, Belgrade- \\ Zemun, 11080; ${ }^{3}$ Faculty of Agryculture, Cacak, 32000; ${ }^{4}$ Institute for Science Application in \\ Agriculture, Belgrade, Serbia \\ *Corresponding author, e-mail: verarajicic@yahoo.com \\ ** Communications
}

Apstract: The aim of this work was parallel investigation of the producting characteristics of light line hen hybrids. Investigation enclosed two hen proveniences: Hisex Brown and Shawer 579.

Within the period of 19 up to 63 weeks we followed next parameters: egg-laying hen body mass, mortality, food consumption and egg-laying capacity.

Hens body mass on the begining of the examination, within the 19 weeks of growth was, for Hisex Brown provenience 1607g, and for Shawer 579 provenience 1563g. Hisex Brown provenience acchieved about $250 \mathrm{~g}$ higher body mass on the end of investigation.

During the experiment, mortality at Hisex Brown egg-laying hen was a little bit smaller $(5,40 \%)$, while the Shawer 579 had 5,56\% of dead hens. Globaly, the mortality at both hen hybrids was in the range of technologycal normative.

The average consumption of the food at Hisex Brown provenience was higher and it was $127,28 \mathrm{~g}$, and at Shawer 579 provenience $125,14 \mathrm{~g}$. The average consumption of the nutrition for egg production at both provenience was the same $(150 \mathrm{~g})$.

Key words: egg-laying,, nutrition consumption, body mass, mortality

\section{Introduction}

Production of the consumption eggs in intensive system is based on the high productive hen hybrids, which have high production feasibilities. 
Contemporary science and practice in hen breading accept a huge number of these hybrids. Often, they were a subject of comparing with the aim of innovating "a better" for certain growing conditions. Large number of investigations shows that beside the established legalities in certain characteristic appearance, there are always less or more essential resignations, compared with established legalities at different hen hybrids as well as in the same hybrids. This kind of investigations always is big contribution to the science and direction in the practice.

Regard the mentioned above, the investigation and comparing of the production characteristics of two line egg-laying hen hybrids for consuming eggs (Hisex Brown and Shawer 579) is very interesting and scientifically and expert justify, and it is very attractive for hen breeders in our country.

As egg-laying hen hybrids in the intensive consumption egg production are usually in usage from 22 up to 72 week, it is logical that their production characteristics as well as egg quality are variable more or less depended on the stature.

\section{Material and methods}

Total number of 3671 hens was used for the investigation of genetic type and the stature influence on the production characteristics of light line hen hybrids. The number of the Hisex Brown hen provenience on the begining of the test was 1151, and Shawer provenience 2520 hens.

After the period of youth breeding, 19 weeks old hens are placed in the same object. During the testing we payed attention as much as possible equalized environment and thechnology of the production and nutrition for the both hen proveniences. The test was finished when the hens were in 63 . week of stature.

The both proveniences was feeded with the fabric livestock concentrate mixture of the fabric «Stizenka», Pozarevac. During the production period the analisys of the mixture was done Agriculture bureau «Stig», Pozarevac.

Control measuring of the body mass took place at the begining of the test, as well at the end of investigation period. The meassuring was done with hanging scale with measuring accurate of $10 \mathrm{~g}$.

With the aim of nutrition consumption fortifying the evidence had been written on the daily base. In accordance with that data, the daily consumption per settled hen was counted (g) and per average hen (g).

In accordance to nutrition consumption and produced eggs for the both production groups it is calculated the consumption of the nutrition for one 
egg production in grams.

Data analisys of the of this examination was performed by usuall methods of variation statistics. The importance of the diferenties testing was done by aplication of the variant analize model which is corespodent to twofactorial experiment.

\section{Results and Disscusion}

The parameters of egg-laying capacity at examined hybrids for the entire 44 weeks investigation lasted period are present in the table 1 .

Table 1. Rate of lay

\begin{tabular}{|l|c|c|}
\hline \multirow{2}{*}{ Characteristics } & \multicolumn{2}{|c|}{ Hybrid } \\
\cline { 2 - 3 } & Shawer 579 & Hisex Brown \\
\hline Number of hens on the begining of the investigation & 2520 & 1151 \\
Number of hens on the end of the investigation & 2380 & 1089 \\
Average number of the hens & 2452,16 & 1119,98 \\
Number of eggs per settled hen & 251,68 & 263,56 \\
- per average hen & 258,72 & 271,04 \\
Egg-laying capacity, \% per settled hen & 81,03 & 85,53 \\
- per average hen & 83,24 & 87,82 \\
\hline
\end{tabular}

According the results in table 1 we can make concluzion that the better egg-laying capacity per settled hen of $85,53 \%$ and per average hen of $87,82 \%$ had Hisex Brown hybrid compared with the Shawer 579 provenience hens which egg-laying capacity was little bit smaller $(81,03 \%$ per settled, respectively $83,24 \%$ per average hen). Regard the point of total eggs number in the examinated period (263,56 at Hisex Brown and 251,68 at Shawer 579) the hens of Hisex Brown hybrib achieved better results.

The egg-laying capacity intensity per weeks of production for the egglaying hen provenience is presented in the graphic 1 .

Looking the graphic 1 where is presented the flow of the average intensity of egg-laying capacity per week of the investigation, for the both group of the hens, it is clear thet the better results were performed during this period by egg-laying hens Hisex Brown hybrid related to the hens of Shawer 579 hybrid.

The maximal egg-laying capacity, examined hybrids showed within the 11.week of their egg-laying capacity, respectively, in $30^{\text {th }}$ week of stature (Hisex Brown 96,99\% and Shawer 93,44\%). In the investigations of Vracar 
et al. (1995), Jashanice et al. (1981) and Petrovic et al. (1981), the maximal egg-laying capacity was much lower, but in the Hartmann et al. (1985) investigations and Bazrdjan et al. (1996) the maximal egg-laying capacity had the similar values.

Graphic 1. Average intensity of the egg-laying capacity per weeks of the investigation, \%

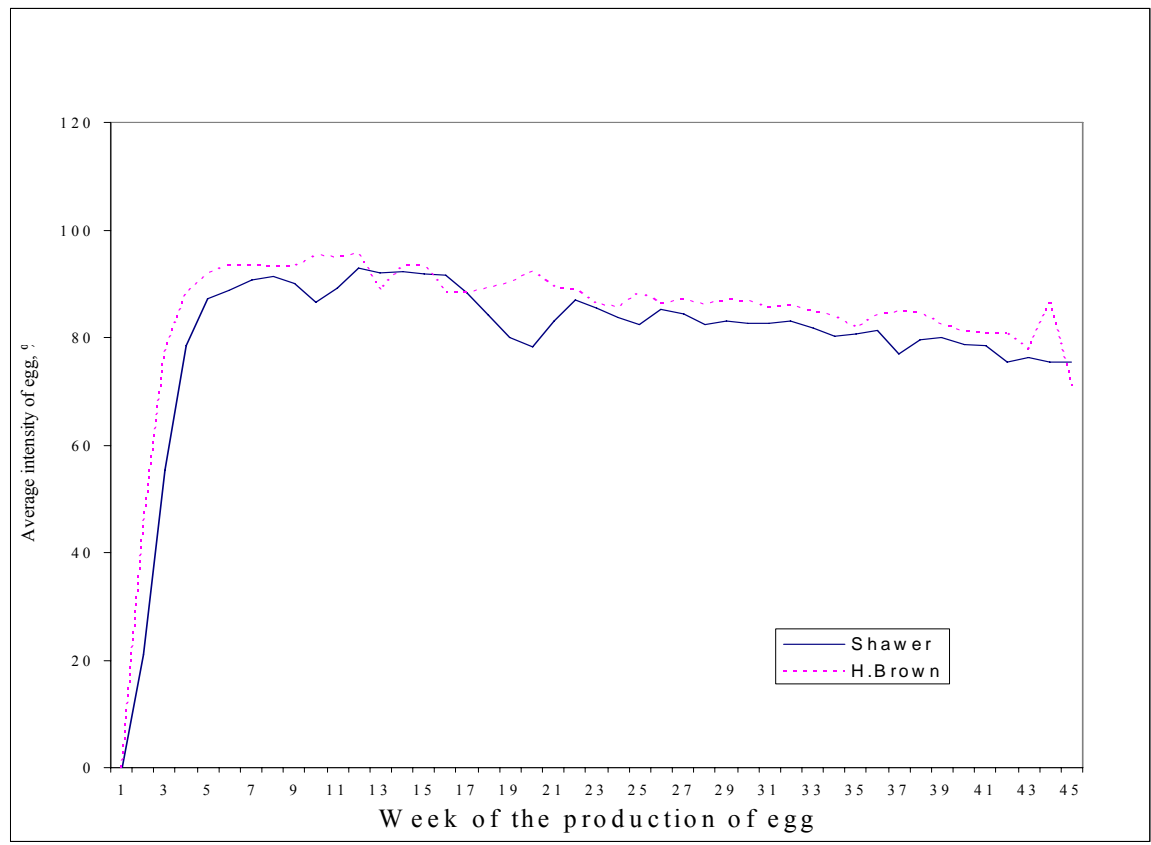

At both hybrids, the coefficient of the corelation regard the stature influence on egg-laying capacity, had midlle, but statisticaly very important corelation $\left(\mathrm{r}=0,501^{* *}\right.$ Shawer and $\mathrm{r}=0,594^{* *}$ Hisex Brown $), \mathrm{P}<0,01$.

Pointed result of examination is in accordance with the results (for the average intensity of egg-laying capacity) got from the authors as Hartmann et al. (1985) and Bazrdjan et al. (1996) are, while Bogosavljevic et al. (1992) and Smerdov et al. (1996) achieved much lower intensity of the egg-laying capacity (about $70 \%$, respectively about $65 \%$ ), with the note that the usage period of commertional flock was longer, 52 weeks.

The parameters of average values and variability of the body mass of the egg-laying hens of investigated hybrids on the begining and on the end of the 
production period are presented in the table 2 .

Table 2. Average body weight of hens, $g$

\begin{tabular}{|l|c|c|c|c|c|c|}
\hline \multicolumn{7}{|c|}{ 19. week of stature } \\
\hline \multicolumn{1}{|c|}{ Hybrid } & $\mathrm{x}$ & $\min$ & $\max$ & $\mathrm{S}_{\mathrm{x}}$ & $\mathrm{S}$ & $\mathrm{CV}$ \\
\hline Shawer 579 & 1564,00 & 1280 & 1760 & 6,55 & 102,44 & 6,55 \\
Hisex Brown & 1616,67 & 1450 & 1800 & 5,76 & 93,16 & 5,76 \\
\hline \multicolumn{7}{|c|}{63 . week of stature } \\
\hline \multicolumn{1}{|c|}{ Hybrid } & $\mathrm{x}$ & $\min$ & $\max$ & $\mathrm{S}_{\mathrm{x}}$ & $\mathrm{S}$ & $\mathrm{CV}$ \\
\hline Shawer 579 & 1688,33 & 1400 & 2200 & 11,15 & 188,32 & 11,15 \\
Hisex Brown & 1935,00 & 1800 & 2200 & 5,08 & 98,39 & 5,08 \\
\hline
\end{tabular}

Regard data showed in the table 2 we can see that the average body mass of the Shawer hens 579 on the begining of the production circle, respectively with 19 weeks of stature, was 1564,0 g, and of the Hisexs Brown provenience $1616,7 \mathrm{~g}$. According that, the body mass of the Hisex Brown hens with 19 weeks of stature was in an average higher for about $50 \mathrm{~g}$ compared to the mass of the Shawer 579 hybrid. In the end of the usage, the average body mass was $1688,33 \mathrm{~g}$ (Shawer 579), respectively 1935,0 g (Hisex Brown). Therefore, we can conclude that the Hisex Brown egg laying hens, on the end of the production period, had about $250 \mathrm{~g}$ higher body mass compared with Shawer 579 hens.

Established value for the average hens mass with 19 weeks is lower compared with data showed by Farrant (1982) and Anokic et al. (1999). The values we got are in corespondance with the values pointed by Vracar et al. (1995), Hopic et al. (1995) and Arapovic et al. (1998).

Values got for the averge body mass of the egg-laying hens in the end of the investigations (with 63 weeks of stature), was lower compared with data pointed by some authors (Farrant 1982, Vracar et al. 1995) and Smerdov et al.(1996)).

Table 3 presents data on nutrition consumption within the whole period of egg-laying hens utilizing.

Regard data showed in the table 3 we can conclude that the average daily nutrition consumption per average hen was higher at the Hisex Brown provenience and it was $127,28 \mathrm{~g}$, and for the hens of Shawer 579 it was $125,14 \mathrm{~g}$. Meanwhile, average consumption of the nutrition based on one egg production was the same for the both hybrids $(150 \mathrm{~g})$.

Total nutrition consumption per hen during the whole investigating period moved from $38,70 \mathrm{~kg}$ at Shawer 579 up to $39,24 \mathrm{~kg}$ at Hisex Brown. 
Established total nutrition consumption per hen is in proportion with the results of Vracar et al. (1995).

Table 3. Average daily feed intake, $g$

\begin{tabular}{|c|c|c|}
\hline \multirow{2}{*}{ Characteristics } & \multicolumn{2}{|c|}{ Hybrid } \\
\cline { 2 - 3 } & Shawer 579 & Hisex Brown \\
\hline Average hen number & 2452,16 & 1119,98 \\
Number of the feeding days & 755264 & 344955 \\
Nutrition consumption per egg, g & 150,00 & 150,00 \\
Average daily nutrition usage, g & & \\
$-\quad \quad$ Per settle hen & 121,62 & 123,94 \\
$-\quad$ Per average hen & 125,14 & 127,28 \\
\hline
\end{tabular}

\section{Conclusion}

Regard above mentioned we could make conclusion that the Hisex Brown hybrid achieved higher body mass and better eggs production during the investigation period. Mortality of the egg-laying hens at the both hybrids was in the range of the technological normatives, while the average nutrition consumption for egg production was the same at the both provenience $(150 \mathrm{~g})$.

Globaly, the both hybrids showed satisfactory results in local breeding conditions. For the majority of characteristics it is established strong or middle corelation dependance between the stature and investigating characteristics.

\section{UTICAJ GENOTIPA I UZRASTA NA PROIZVODNE OSOBINE LAKIH LINIJSKIH HIBRIDA KOKOŠI}

V. Rajičić, S. Mitrović, S. Bogosavljević-Bošković, J. Milivojević, M. Staletić, V. Đermanović, N. Tolimir

\section{Rezime}

Cilj ovog rada bio je da se izvrši uporedno ispitivanje proizvodnih 
sposobnosti lakih linijskih hibrida kokoši. Ispitivanjima su obuhvaćene dve provenijence kokoši: Hisex Brown i Shawer 579.

U periodu od 19. do 63. nedelje starosti praćeni su sledeći parametri: telesna masa nosilja, mortalitet, utrošak hrane i nosivost.

Telesna masa kokoši na početku ispitivanja, sa 19 nedelja uzrasta, za provenijencu Hisex Brown, iznosila je 1607 g, a za provenijencu Shawer 579-1563 g. Veću telesnu masu na kraju eksperimenta, za oko 250 g postigle su nosilje provenijence Hisex Brown.

U toku ispitivanja, mortalitet kod Hisex Brown nosilja je bio nešto manji $(5,40 \%)$, dok je Shawer 579 imao 5,56\% uginulih nosilja. Posmatrano u celini, mortalitet nosilja kod oba hibrida, bio je u granicama tehnoloških normativa.

Prosečna dnevna potrošnja hrane kod provenijence Hisex Brown je veća i iznosila je 127,28 g, a kod Shawer 579-125,14 g. Prosečna potrošnja hrane za proizvodnju jajeta kod obe provenijence je bila ista $(150 \mathrm{~g})$.

Ključne reči: nosivost, utrošak hrane, telesna masa, mortalitet

\section{References}

ANOKIC N., SMERDOV S., TOLIMIR N., HRKALOVIC D., MAKSIMOVIC S., MASIC B. (1999): The influence of the breeding conditions and stature on the body mass of the egg-laying hens, The science of poultry raising, 4, 1-2, 7-14, Belgrade.

ARAPOVIC Z., PERIC L., TOROVIC M., KONJEVIC S. (1998): The breeding resalts on light line hybrids Shawer 579 and Tetra-SL, The science of poultry raising, 3, 3-4, 447-452.

BAZRDJAN M., TOLIMIR N., MASIC B. (1996): The influence of stature, population and cage position in the battery on the egg-laying capacity of the small Hisex Brown hens flock, Poultry raising, 5-6.

BOGOSAVLJEVIC-BOSKOVIC S., MITROVIC S., STOLIC N. (1992): Analysis of the producing results Isabrawn hen hybrids in the vertical transportablle batteries breeding. Seminar "Innovations on cattle breeding", X, 37-42, Belgrade-Zemun.

FARRANT J. (1982): Fcr comes down for brown and white. World Poultry Industry, February.

HARTMANN W., HEIL G. (1985): Predict performance differences Poultra-Misset, 26-29.

JASHANICA H., BAKRI Z., VUKSA, Lj., GRUDA E., BAKALLI R. 
(1981): Hybrids production results SSL in the conditions of poultry farm. Processing, 11-12, 46-48.

PETROVIC V., KRSTIC N., KRSTIC S., MITROVIC S., TOMIC S. (1981): Enclosure to acquainted with production capabilities De Kalb hybrids. Processing, 2, 11-12.

SMERDOV S., HRKALOVIC D., ANOKIC N., TOLIMAR N., MITROVIC S., MASIC B. (1996): Tetra Sl i Harco egg-laying hens production in the same conditions of keeping and feeding., Poultry raising, 9-10.

VRACAR S., MITROVIC S., HOPIC S., DJURDJEVIC Z. (1995): Egglaying hens genetic type and stature influence on external characteristics of egg quality. Biotechnology in cattle breeding, 3-6, 307-314.

HOPIC S., VRACAR S., MITROVIC S., DJURDJEVIC Z. (1995): Egglaying hens genetic type and stature influence on internal characteristics of egg quality. Biotechnology in cattle breeding, 3-6, 315-323. 